\title{
Endodontology: An Integrated Biological and Clinical View
}

\author{
Domenico Ricucci, José F. Siqueira Jr \\ Publisher: Quintessence Publishing Co Inc \\ Language: English \\ ISBN: 978-1-85097-264-8 \\ Edition: 1/e \\ Publish Year: 2013 \\ Pages: 440, illustrated \\ Price: $\$ 258.00$
}

Dr Domenico Ricucci and Dr José Siqueira Jr present the readers with a monumental atlas and a textbook on Endodontology that underscores the biological foundation of endodontic treatment. The book is divided into 10 chapters. The first chapter presents a review of the dentin-pulp complex and periradicular tissues at the microscopic level. The pulp response to caries and restorative procedures in terms of physiology and pathology is described in the second chapter. The third chapter details the vital pulp therapy, from deep caries treatment to pulpotomy supported by excellent clinical photographs. Chapters four and five describe the endodontic periradicular pathology and clinical cases with infection correlated with microscopic images. The next two chapters describe the clinical treatment procedures of nonvital teeth and the periradicular expcted tissue response to enhance the understanding of endodontic treatment. The eighth chapter is dedicated to exploring the effect of lateral canals in the endodotic field. The penultimate chapter examines the complex causes

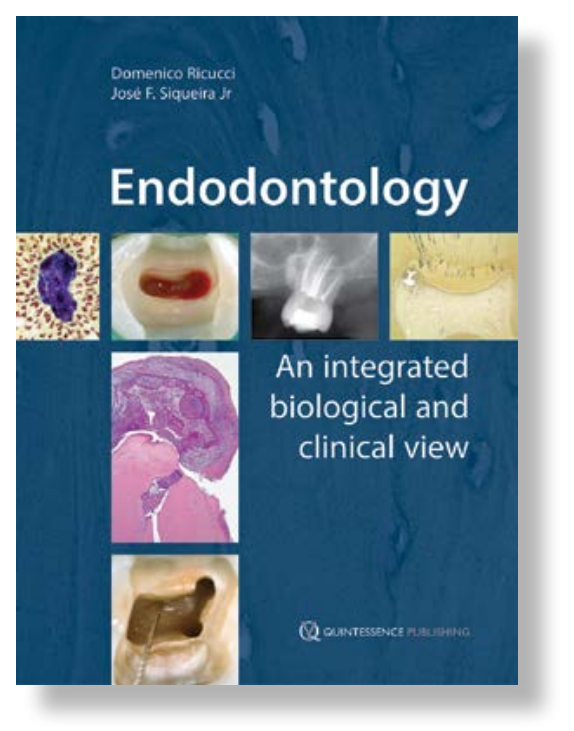

for endodontic treatment failures. The last chapter describes the endodontic-periodontal meaningful interrelationship supported by conclusive documentation.

The book is a clinical essential textbook for comprehensive endodontics at undergraduate and graduate levels, including specialists, professors and researchers. The book can help improve your knowledge of the anatomy, physiology and pathology of the dentin-pulp response and periradicular complex to the modern treatment tissues techniques.

https://doi.org/10.25241/stomaeduj.2015.2(2).bookreview.5

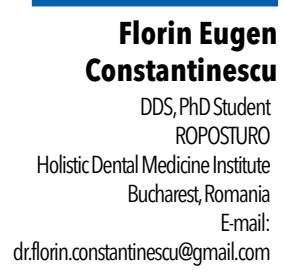

The Book Review is drafted in the reviwer's sole wording and illustrates his opinions. 